\title{
Roles Mapping in Tribal Conflict Reconciliation: A Study from West Kalimantan Dayak and Madurese Case
}

\author{
Ira Mirawati \\ Communication Management Department, Universitas Padjadjaran, Jatinangor-Sumedang \\ E-mail: ira.mirawati@unpad.ac.id
}

\begin{abstract}
The Tribal conflict between Dayak and Madurese of West Kalimantan in 1996 - 2000 causing their communication had totally broken for many years. In 2002, they began to communicate. Until now, they still improve their communication quality. It is important to know how they conduct this reconciliation communication after all of their conflict. This research investigates people roles in the reconciliation communication between Dayak and Madurese in Kabupaten Bengkayang, West Kalimantan. Researcher using in-depth interview, observation, and literature study in this Phenomenology research. Nineteen informants were chosen purposively. They are both Dayak and Madurese, people from other tribe, police, and government officer. The result shows there are four roles in this communication; they are Dayaknese and Madurese as the main actor or performer, the guarantor as a mediator, the police officer and local government officer as an advisor, and other ethnics as colleagues. Madurese needs guarantor to ensure their live. Dayak and Madurese need an advisor when they facing a problem. Both of them also need other ethnics as colleagues to smooth communication. All of them played a role dramaturgically in positive purposes, as a personal or as a team member.
\end{abstract}

Keywords: role mapping, reconciliation, tribal conflict, Dayaknese Madurese, dramaturgy

\begin{abstract}
Abstrak. Konflik antarsuku Dayak dan Madura pada tahun 1996 - 2000 di Kalimantan Barat menyebabkan komunikasi mereka benar-benar hancur selama bertahun-tahun. Pada 2002, mereka mulai berkomunikasi. Jalinan komunikasi mereka rajut secara perlahan dan penuh pertimbangan. Orang-orang Madura dan Dayak memilih perilaku secara matang karena mereka yang menjalin komunikasi adalah pihak yang saling memerlukan satu sama lain. Penting untuk mengetahui bagaimana mereka melakukan komunikasi rekonsiliasi ini setelah konflik berdarah tersebut terjadi. Penelitian ini meneliti peran-peran yang ada dalam komunikasi rekonsiliasi antara orang Dayak dan Madura di Kabupaten Bengkayang, Kalimantan Barat. Pada penelitian fenomenologi ini, peneliti menggunakan wawancara mendalam, observasi, dan studi pustaka. Sembilan belas informan dipilih secara purposif. Mereka terdiri dari orang Dayak dan Madura, orang-orang dari suku lain, polisi, dan petugas pemerintah. Hasilnya menunjukkan ada empat peran dalam komunikasi ini yakni orang Dayak dan Madura sebagai aktor utama atau pemain, penjamin sebagai mediator, petugas polisi dan pejabat pemerintah daerah sebagai penasihat, dan etnis lainnya sebagai rekan kerja. Orang Madura membutuhkan penjamin untuk memastikan keselamatan nyawa mereka. Orang Dayak dan Madura membutuhkan penasehat saat mereka menghadapi masalah bersama. Keduanya juga membutuhkan etnik lain sebagai kolega untuk kelancaran komunikasi. Semuanya memainkan peran secara dramaturgi dalam tujuan positif, baik sebagai pribadi atau sebagai anggota tim.
\end{abstract}

Kata kunci: pemetaan peran, rekonsiliasi, konflik kesukuan, orang Madura Dayak, dramaturgi 


\section{INTRODUCTION}

Tribal conflict in West Kalimantan has a very long history. In the 70 s there was a conflict between the Dayaknese and Chinese. This conflict caused Chinese to be driven from inland in Monterado and Bengkayang Regency into Singkawang. Conflict has also occurred between Malays and Madurese. The conflict, based in Sambas district, occurred in 1999 and 2000, and has not been completed resolved until now. Madurese people cannot stay even visit Sambas district. If there are Madurese who try to get into Sambas district, then certainly he will not be able to get out safely.

Beside the interethnic conflict, in West Kalimantan there has also been a conflict between Dayak and Police. However, among all the conflicts that have raged, the most notorious, largest and prolonged conflict is between Dayak and Madurese. The conflict that West Kalimantan residents call it "Perang Suku" has actually started since the 1950s. Among many tribal conflicts that occurred in Indonesia, conflict between Dayak and Madurese is a conflict that happen all over again (Smith, 2012). This tribal conflict reoccurred in 1977 and 1979. Nearly 20 years later, in 1996, a dispute between some Dayak and Madurese youth in Sanggau Ledo, Sub-district of Bengkayang, reignited the conflict of both tribes (Davidson \& Kammen, 2002: 54).

Dayak and Madurese, both are often have conflict with other ethnic. One of the reason is, the existence of "mengayau" in Dayak and "carok" in Madurese. Those are belligerent cultures when disputing with other groups (or even their own groups) (Arkanuddin, 2005:186).

However, now the conflict has subsided and the atmosphere has gradually returned to peace, although in some areas the Dayak still resist to Madurese. Not all areas that have been occupied by Dayak "totally reject" the presence of
Madurese. In certain locations, especially in Bengkayang regency, Dayak "allowed" or give "permission" to some Madurese people to enter the area. The term "Permit" does not explicitly in written form, but Dayak allowed them to enter their territory. Dayak people do not persecuted or killed them. For Dayak, territory is one of the most important aspect of their identity (Peluso \& Harwell, 2001:86)

One of the areas in Bengkayang Regency that Dayak allowed Madurese to enter is the District of Monterado. This region is one of the areas where the tribal conflict at most casualties. There is no official record of the casualties' exact number, but according to Briptu Musadad, local police officer of Monterado, about 200 houses were burnt and the casualties reached hundreds. The remaining Madurese almost entirely fled to Singkawang. They then live in Roban district, Singkawang.

The distance between Madurese refugee camps in Roban and Monterado, which is currently occupied by Dayak, is not too far, about $20 \mathrm{~km}$. Therefore, the mobility between these two places is also not difficult. Moreover, road conditions are also very conducive. Therefore, there are no barriers in infrastructure for them to communicate. The re-assembly of this communication is certainly a good starting point. Madurese expected to improve relationships that have been disconnected. However, one of communication principle is irreversible. Aubrey Fisher and Adams state "A behavior is an event. Because it is an event, the behavior takes place in time and cannot be "taken back". People can forgive but can't forgot (Mulyana, 2000: 112). Communication can only go forward from one state to another, from equilibrium to a new equilibrium, never returning to their original state (Barnlund, 1970: 52).

The Tribal conflict has taken place, and the time and conditions cannot be restored exactly as they were when it has not occurred. What the members 
of both tribes can do is to reestablish communication, with a new meaning different from the meaning before the tribal conflict.

Before the tribal conflict, Dayak and Madurese in communicating always delivered their "at will" message. In a sense, they communicate according to their respective cultures and do not pay attention to the cultures of their interlocutors. Now that the Tribal conflict has occurred and the casualties have fallen on both sides, there is a difference in their communication. Ade, a resident of Monterado, said that both tribes now look "smoother" and polite in communicating. According to him, each tribe more careful in communicating as if avoids to offend the interlocutor.

Description of Ade, showing early indications of the impression management efforts carried out by each tribe in postconflict communications. Impression management is the technique used by communicators to foster certain impressions in certain situations to achieve certain goals (Mulyana, 2001: 112). This concept is known in the Dramaturgy theory of Erving Goffman. Impression management conducted as they played their role. Roles are people expectation, which are socially defined to some person to plays an action in a some situation to give a particular image to the audience (Mulyana, 2001: 109). Impression management consists of defensive techniques and protective techniques. Defensive techniques are performed before communication begins, consisting of: 1) Dramaturgical loyalty or work to keep loyal team members to other team members and the show itself; 2) Dramaturgical discipline or dedicating our self to the show but without losing the identity. Sometimes, people need to do exercise; 3) Dramaturgical circumspection, which minimizes risk by preparing for problems that may arise. Be careful to avoid situations where errors or potential problems can occur, choosing the right audience, time, and place.

According to Jerold Heiss (Mulyana, 2001: 136) impression management is used to present selfimage, both true and false. Impression management is something inherent in our social interaction. It is neither good nor bad. Everyone, conscious or no, gets involved in it every day. In Goffman's view, humans interact in self-presentation as honest and dishonest actors. This selfconcept also applies to the formation of ethnic identity in the sense that the concept of self is placed in the context of authenticity, so that the self is culturally specific and based on the authenticity. A study conducted by Karomani shows that people do manage the impression on people who must be respected (Karomani, 2005: 354).

The change in communication behavior by both tribes member is an early indication of each tribe intention to reconcile and improve communication. There is no short cut or simple prescription for creating trust and understanding after violence conflict. Both parties need to build the interaction, and transcend it together. Reconciliation means the use of the past as the seed of renewed conflict. It concatenates peace, severs the cycle of violence, and strengthens newly established relationship (Bloomfield \& Barnes, 2003: 19).

Reconciliation is a long terms process. It may be need years and decades. Luc Huyse, professor of Sociology of University of Leuven Belgium, and consultant for many conflict reconciliation is Africa, states that reconciliation needs three major stages. There are replacing fear by non- violent coexistence, building confident and trust, and understanding with empathy. All stages, not only individual task. It is the work of groups and communities as a whole (Bloomfield \& Barnes, 2003: 19-21).

In the conflict of Dayak and Madurese, everybody, in the perspective of personal and the collective, has its 
own role that equally important the reconciliation process. This research investigates people roles in reconciliation communication between Dayak and Madurese in Kabupaten Bengkayang, West Kalimantan. They need to redefine their respective roles in order for communication to proceed as expected. It is because as DeVito explained, the concept of intercultural communication refers to the process of communication between people of different faiths, values, or ways of behaving culturally (1997: 479). Without considering their expected roles, communication will not running smoothly.

\section{METHODS}

To investigate and map the roles in reconciliation communication process between members of Dayak and Madurese, the authors use qualitative research methods with the tradition of phenomenology. The character of qualitative phenomenological research is to observe and interact with research subjects to try understanding the language and their interpretation of the world. Studies with a phenomenological approach attempt to explain the meaning of the life experiences of some people about a concept or phenomenon, including the self-concept or view of their own lives (Cresswell, 1998: 51). In addition, this paradigm requires researchers to entering the conceptual world of subjects in such a way that researchers understand what and how a sense developed by them around events in everyday life (Moleong 1993: 9). This means that research with a phenomenological approach takes place in a natural place and time.

With all the characteristics of phenomenology approach, it will get holistic data about the communication of Dayak and Madurese after tribal conflict communication, so researcher can find how are they manage their role in to impress others.

Robert Bogdan and Steven J.
Taylor mention two main approaches in the phenomenological tradition, symbolic interactionism and ethnomethodology (2000: 119-188). From some branches of the phenomenology tradition, researchers use a model of symbolic interactionism. This model fits the focus of the study, because the most fundamental proposition of symbolic interactionism is that human behavior and interaction can be distinguished because it is represented by symbols and their meanings. Finding the meaning behind the sensual is something that is important in symbolic interactionism (Muhadjir, 2000: 183).

To collect data, researcher using in-depth interview, observation, and literature study. Nineteen informants were chosen purposively. They are both Dayak and Madurese, people from other tribe (Malay, Sundanese, and Javanese), police officer, and government officer.

\section{RESULTS AND DISCUSSION}

Although Dayak are the majority population, but not automatically their culture becomes the dominant. Each ethnic group adheres to their own cultures. Each ethnic group has a tendency to form a group of its own and has the special characteristic physiologically, linguistically, socially, and economically, which becomes the identity of the group members. Dayak build up their identity through extensive mechanism. Sumadi Dila (Dila, 2005:322) state that internally every ethnic member conduct selfaffirmation and self-assessment. Thus, they adapt their identity in wider context through social participation, organization and working environment. All parties need dialogue.

The not dominant of Dayak culture looks conspicuous is the use of language. In everyday conversations with Dayak, they use their own language, whereas with people of different ethnicity or with unknown persons the language used is Malay. The use of Malay language is inseparable from its similarity with 
Indonesian so it can be understood by all ethnic and can accommodate them in communicating.

In terms of settlement, there is no visible difference between all ethnic. The average resident builds a modern permanent house, not a traditional house. Dayak in the District of Monterado no longer live in longhouses (rumah betang). The Dayaks live in permanent homes. However, most of them also have nonpermanent residences (huts) on farms or plantations, which can reach tens of kilometers from their homes. No typical home furnishings characterize a house as a Dayak. They do not display mandau, chopsticks, or Dayak shields. A feature more easily seen in Dayak settlements is in pets. Dayak people usually keep dogs and pigs free to roam around their homes, while other tribes no. Physically, Dayak lifestyle in Monterado Bengkayang is not much different from other ethnic. They do not use Dayak clothes and accessories.

On the other side, In West Kalimantan, Madurese ethnic residents are scattered in various regions. They can settle in areas with various conditions. In general, they live in groups of a settlement. Before the latest tribal conflict occurs, some large settlements where Madurese lives are Siantan Pontianak, Peniraman, Sei Pinyuh, Karimunting, Roban Singkawang, and Monterado Bengkayang.

The social ties in Madurese are very strong; this can be proven by the mutual recognition of Madurese ethnic in Monterado with the Madurese in other areas. Their strong social and solidarity ties also show by helping new migrants who have not had a place to live by accommodating them until they can have a place to live. Solidarity is also shown by helping families who are threatened by other families from the same ethnic as well as from other ethnic groups.

Madurese in Monterado make their hometown like their hometown, not only physical but also cultural. They brought both positive and negative cultures. Negative cultures include the cockfight culture and the "carok" culture. Carok is fighting others who become enemies by using sharp weapons, both celurit (Sickle) and parang (machetes). Fighting enemies can come from other ethnic and ethnic Madurese themselves. In some cases, they do carok against their own relatives. Carok for the Madurese is a form of fulfillment of issues related to defense of their self-esteem.

In addition to the negative culture, Madurese also bring many positive cultures. One among these positive cultures is their diligent and hardworking culture. Persistence and hard work are one of Madurese personality traits, so many of them are successful and have high economic levels.

\section{Roles in Dramaturgy Theory}

There are three fundamental roles in Goffman's theory, each of which corresponds to a different type of information. The three roles are performer, audience, and outsider. Performer is an actor, who plays both on the front stage and backstage. They are aware of the impression they are developing and have information about the shows they perform. In communication between Dayak and Madurese the performer are a member of Dayak and Madurese itself. When communicating, they mutually become performers. While Dayak became a performer, he also became an audience. Similarly vice versa with Madurese. While playing a role in performing in front of Dayak, Madurese also became an audience that watched the performance of Dayak. As a performer, they develop an impression and information to create or control perceptions on the other person. Conversely, when become the audience, they possible to see what other person shows.

In addition, there are performers and audiences, in intercultural communication between Dayak and Madurese there is 
Ira Mirawati, Roles Maping in Tribal Conflict Reconciliation: A Study from...

TABLE 1. Research Informants

\begin{tabular}{lll}
\hline Name & Tribe/Age & Sex \\
\hline Sariman & Malay/30 & Male \\
Bu Umi & Madurese/60 & Female \\
Maskun & Madurese/40 & Male \\
Arman & Madurese/38 & Male \\
Raska & Madurese/37 & Male \\
Ela & Malay/24 & Female \\
Mawar & Malay/42 & Female \\
Hasan & Sundanese/40 & Male \\
Ade & Sundanese/44 & Female \\
Bantat & Dayak/30 & Male \\
Raga & Dayak/35 & Male \\
Didiy & Dayak/55 & Male \\
Inis & Dayak/50 & Male \\
Marcil & Dayak/40 & Female \\
Musadad & Sunda/52 & Male \\
Santana & Malay-javanese/48 & Male \\
Lina & Sunda/21 & Female \\
Saryah & Malay/23 & Female \\
\hline
\end{tabular}

exist an outsider. Outsiders are those who know the secrets of the actors or the realities they develop. Who is the outsider in this inter-ethnic communication? What can be said as outsider are those who are not Ethnic Dayak or Madura but live together with Ethnic Dayak or Ethnic Madura. They are other ethnic members who marry Dayak or Madurese. Other ethnic groups who married Ethnic Dayak are Lina (ethnic Malay 21 years old), while those married to Madurese are Saryah (23-year-old Malay ethnic).

The other party, which can also be said as outsider, is the guarantor. The Guarantor is a Dayak who guarantees the Madurese that the Dayaks will not harm them when they are in the sub-district of Monterado. These guarantors are the people who need labor from Ethnic Madurese. One of the guarantors is Inis, the owner of stone mining, whose identity has been mentioned by researchers in the Table 1.

Others whose has role as an outsiders are other ethnic groups who witnessed the communication of Dayak and Madurese, but they also know the behavior of the two ethnic communications when they are not dealing in a communication or when the informants from the Dayak and Madurese are communicating with other ethnic groups. They are Mawar, Ela, Bu Ade, and Hasan, who intensively communicate with the two ethnic groups.

\section{Roles Related to Information Manipulation and Group Boundaries}

The informer; Someone who pretends to performers as members of their group to be allowed to know backstage, but then sells it to an audience. An example of this role is the spy. In this Dayak and Madurese interethnic communication, researchers are cannot find any outsiders who become a spy.

Everyone in the Monterado has been traumatized by the past. The Dayak also, although they we can say that they are obviously "the winners", they still do not want the incident to happen again. 
If it happens, again they can no longer occupy the land of Madurese relics they now occupy.

"Because now all Madura heritage land is under the supervision of the Local Government [Bengkayang Regency Government] and the [police] apparatus. Dayak feel safe. They do not afraid Madurese will take it forcefully. That's why Dayak also avoid conflict with Madurese. Moreover, for Madurese, obviously they really do not want the conflict happen again. It is the same with other tribes. Other tribe, beside Madurese is actually the victims of this conflict. Many of them also lost their property. I am sure there are not any people here who want to incite one of the two tribes. It is enough that the earlier [Tribal conflict] happened".

The statement above, researchers get from Briptu Musadad. The statement implies that no one is a spy or the informer in the communication.

Another role related to information manipulation and group boundaries is the "Shill". The Shill if translated into Indonesian is brokers, i.e. someone who behaves as part of the audience but in fact, he works with performers. His job is to manipulate or direct the audience's reaction. In the Dayak and Madurese communication in the District of Monterado, the researchers did not find the party who acted as the shill. No particular party is attempting to manipulate and direct the reaction of the two ethnic groups. They communicate according to their wants and needs.

The last role relating to the manipulation of information and group boundaries is the "Spotter", translated into Indonesian means the eraser, a person who acts as an inventor or fraud in

TABLE 2. Informants Role in Dayak and Madurese Communication

\begin{tabular}{lll}
\hline Name & Residence Status/Occupation & Role \\
\hline Sariman (Malay) & Permanent/ Rubber tree Farmer & Performer \\
Bu Umi (Madurese) & Impermanent/ Housewife & Performer \\
Maskun (Madurese) & Impermanent/ Vegetable seller & Performer \\
Arman (Madurese) & $\begin{array}{l}\text { Impermanent/ Vegetable Farmer \& Sate } \\
\text { seller }\end{array}$ & Performer \\
Raska (Madurese) & Impermanent/ Mining worker & Performer \\
Ela (Malay) & Permanent/ Seller & Outsider \\
Mawar (Malay) & Permanent/ubber tree Farmer & Outsider \\
Hasan (Sundanese) & Permanent/ Rubber tree Farmer & Outsider \\
Ade (Sundanese) & Permanent/ Rubber tree Farmer & Outsider \\
Bantat (Dayaknese) & Permanent/Seller & Performer \\
Raga (Dayaknese) & Permanent/ Rubber tree Farmer & Performer \\
Didiy (Dayaknese) & Permanent/ Rubber tree Farmer & Performer \\
Inis (Dayaknese) & Permanent/Stone Mining Owner & Performer \\
Marcil (Dayaknese) & Permanent/ Rubber tree Farmer & Performer \\
Musadad (Sundanese) & Permanent/Police officer & Outsider \\
Santana (Malay-Java- & Impermanent/ District Government Officer & Outsider \\
nese) & & Outsider \\
Lina (Sundanese) & Permanent/Seller & Outsider \\
Saryah (Malay) & Permanent/Housewife & \\
\hline
\end{tabular}


the audience, but behaves for the benefit of the audience, not the performers. He plays the role of examining performers and can provide destructive information to the audience. In research on communication Dayak and Madurese in District Monterado is also there is no the spotter. Neither party attempts to provide destructive information to those formerly conflicted. This condition occurs because destructive information will cause an offense on one ethnic. People in the Subdistrict of Monterado realize that a sense of offense - no matter how small - can lead to deadly conflicts. An example of this is the War of the Tribe itself. The Tribal Conflict, which claimed thousands of lives, was caused by minor tribulations on both sides. Madurese are offended because his female friend is approached by Dayak. He then stabs the young Dayak. Furthermore, almost all ethnic Dayak are offended when hearing destructive information that says that Dayak people died. Finally, the tribal conflict took place.

\section{Roles Related to Facilitate Interaction Between Two Teams}

The "go-between" or "mediator". He learns the secrets of both parties (usually with the permission of both parties) and acts as a mediator or messenger, facilitating their communication. $\mathrm{He}$ can be neutral or not. Researchers found that in this Dayak and Madurese communication there are parties acting as go between or mediator. They are the guarantor. These guarantors, as explained above, are Dayaks who guarantee the safety of Madurese to work, including communicating with Dayak. They guarantee that the Dayak will not harm the Madurese they assure, those who work in their stone quarries. This guarantee is, of course, as long as the Madurese did not make a move or do not do things that could offend and harm the Dayak. The guarantor also gives assurances to the Dayaks that these Madurese will not do things that could harm the Dayak.

In this study, researchers also tried to find out whether the authorities are both government officials and security personnel acting as mediators. Supposedly, the apparatus is a party that seeks to facilitate the two groups can return to live side by side and communicate well. Here are the results of

TABLE 3. Specific Roles Identification

\begin{tabular}{lll}
\hline No & Roles & Subject \\
\hline 1 & The Informer & No One \\
2 & The Shill & No one \\
3 & The Spotter & No one \\
1 & The "go-between" atau "mediator". & The guarantor \\
1 & The "non-person" & No one \\
2 & The "service specialist" & Police officer who deeply understand the \\
& & condition of Dayaknese and Madurese in \\
& & Sub District of Monterado \\
3 & The "collegue" & Other tribe member who communicate \\
& & with Dayaknese and Madurese. They are \\
& & Malays, Sundanese, and other ethnicities. \\
& Those who marry Dayak or Ethnic Mad- \\
4 & The "confidant" & urese. They know and become their hus- \\
& & bands'right man hand in relation to their \\
& impressions.
\end{tabular}


the research interview with Santana:

"No, we don't have special program in initiating their reconciliation. It is too complicated and we do not have the human resource. However, we do help them. We help them when they asking as becoming the mediator especially when they try to settle some administration matter about their land and home ownership"

From the interview with Santana, Monterado Government officer, we conclude that the government apparatus does not create programs that can facilitate the inter-communications network of Dayak and Madurese.

Previous research conducted on the Dayak and Madurese conflicts indicates that the role of government as a mediator, in the short term can stop open conflict. It is necessary step further government as mediator and adviser in daily life of both ethnic so that harmony stay awake in long term (Alexandra, 2014).

\section{Roles that Mix the Front and Back Areas}

The "non-person" are those who were present during the interaction on the back stage but did not take on the role of performer or audience. They are not part of the team and are usually ignored. An example is cleaning service.

In the Dayak and Madurese communication in the District of Monterado there is no such non-person. The people present on the back stage, although they are not a team or not part of the team but still their presence is very conscious and not ignored.

The "service specialist", is the person who knows something about the setting. They are on the backstage at the request of the team to help performing with the expertise. In this study, researchers found a party that can be called a service specialist. He is Briptu Musadad, who is also an informant in this research.
Briptu Musadad is a police officer who has been in charge of Monterado since 1984. During the Tribal conflict he was always on guard in Monterado. $\mathrm{He}$ is from the Sundanese ethnic group. Briptu Musadad can be regarded as a service specialist because he is usually invited by Dayaknese and madurese to solve their problems relating with land, property, and farm ownership status.

According to Musadad, there is actually a tendency of Dayaknese and Madurese to seek advice from the police especially those from Sundanese ethnic, because during this time Sunda ethnic never have a conflict with Dayak or Madurese. Unfortunately, not all Sundanese police can be asked for advice including the Police Chief of Monterado. Dayak and Madurese are reluctant to consult or seek advice to him because he was newly assigned in Monterado for 2 years. They think people who have lived in Monterado for 2 years have not understood deeply the condition of the Monterado's people.

In addition to the service Specialist, in the Dayak and Madurese communication there is also the "colleague", i.e. people who perform the same routine with the same audience but not participate simultaneously. The role of this colleague is the other ethnic who communicate with Dayak and Madurese. They are Malays, Sundanese, and other ethnicities.

The "confidant," a person to whom the performer can "confesses his/ her sins," freely tells the details of the impression they displayed. In this Dayak and Madurese communication, which can be regarded as the confidant are those who marry Dayak. They know and become their husbands' beliefs in relation to their impressions.

Reconciliation between Dayak and Madurese in this Monterado subdistrict takes more than five years after the conflict to be started. It is still on the process until now. The communication 
that occurs between them goes slowly but can surpass the stages of reconciliation to harmony. Stages traversed by these two tribes, in fact, in line with the stages proposed by Bloomfield \& Barnes (2003: 19-21).

The first stage, replacing fear by non-violent coexistence is done by establishing a positive perception that the people they are going to meet are the ones that when the tribal conflict happens is not the troop who fought. Madurese build the perception that the people who will be their communication partners are Dayak who have a business that requires labor or Dayak who need Madurese as a supplier of vegetables and other food products. Meanwhile Dayak build a positive perception that Madurese who enter Monterado are good people whose sole purpose is to find work or earn a living by selling vegetables.

The second stage, building confident and trust more awakened when they already communicate with each other. They found that their communications partner, who though from a warring tribe, was an individually trustworthy person. Other tribe also supporting them by becoming a colleague who always give them positive advice which strengthening their confident and trust.

The third stage, understanding with empathy occurs when they dialogue and then seek a mutually beneficial way out of various conditions. For example, Madurese want their land to be bought, Dayak empathize because the Madurese who asked for this can show the land certificates. Otherwise the Madurese can understand if the Dayak people who will buy claim to pay by installments because their financial condition.

They realize that all stages, not only individual tasks. It is the work of groups and communities as a whole. Madurese needs guarantor to ensure their live. Dayak and Madurese need advisor when they facing a problem. Both of them also need other ethnics as colleagues to smooth communication.

In the environment of conflict, impression management is needed as an integral part of both ethnic in performing reconciliation. Impression management helping them showing their best personal and group image, helping them restraint negative behavior, and helping them pursuing the harmony.

Both Dayak and Madurese must notice that reconciliation is a process, which includes the search for truth, justice, forgiveness, and healing. As Bloomfield (Bloomfield \& Barnes, 2003: 12) said, reconciliation means finding a way to live alongside former enemies, to love and to forgive them. They need conduct impression management because they "must forget" the past in anyway, but to coexist with them. They consider developing cooperation necessary to share their society, so that they can have better live together than live separately.

\section{CONCLUSIONS}

In the scope of Dayak and Madurese post-conflict communications in this district of Monterado, in accordance with the results of research that has been described in advance, researchers formulate the roles involved in such communication as follows: 1) Performer, those who become the main actors in this communication. They are Dayak and Madurese. They act as communicators as well as playing roleas an audience; 2) Mediator, performs the role of mediating communication between ethnic Dayak and Madurese. Mediator in this case done by the guarantor. By ensuring the safety of the Madurese working in the mines he cultivated the courage of the Madurese to begin communicating. Similarly, by ensuring that Madurese will not commit harmful acts, the guarantor makes Dayak sincerely accept the re-entry of Madurese; 3) Adviser, they only give advises when asked by one or both parties. The advice relates to what they should do when faced with a problem. The advisors 
in this communications are the police officer that they consider to be very well informed of the about conflict in the SubDistrict of Monterado; 4) Colleague, other ethnics who are equally communicating during Dayak and Madurese interethnic communication. The colleagues in the monterado district are colleagues for both tribe.

Reconciliation between Dayak and Madurese in Monterado is initiates by themselves. In fact, tribal conflicts or other social conflicts are frequently occurs in Indonesia. It is crucial that Indonesians government has a strategic reconciliation program for similar cases. They need identify critical factors and potential solution in order to construct variety strategic and structural choices.

\section{REFERENCES}

Alexandra, F. (2014). Analisis Efektivitas Resolusi Konflik Sampit pada Tahun 2001. Yogyakarta: Universitas Gajah Mada.

Arkanuddin. (2005 ). Menelusuri Akar Konflik Antaretnik di Kalimantan Barat. Mediator Vol 7 No 2, 185-195.

Barnlund, D. C. (1970). Language Behavior:A Book of Readings In Communication. The Hague: Mouton.

Bloomfield, David \& Barnes, T. (2003). Reconciliation After Violence Conflict: a Handbook, Stockholm: International Institute for Democracy and Electoral Assistance.

Cresswell, J. W. (1998). Qualitative Inquiry and Research Design Choosing Among Five Tradition. California: Sage Publication.
Davidson, J. S., \& Kammen, D. (2002). "Indonesia's Unknown War and the Lineages of Violence in West Kalimantan." Indonesia No 73, 54.

DeVito, J. A. (1997). Komunikasi Antarmanusia (The Interpersonal Communication Book). Professional Book: Jakarta.

Dila, S. (2005). "Simbolisasi Etnik Muna di Bandung:Studi Identitas Etnik Orang Muna." Mediator Vol 9 No 2, 317-326.

Karomani. (2005). Studi tentang Pengelolaan Kesan Elite Lokal Umaro terhadap Jawara dan Ulama di Banten Selatan. Mediator Vol 9 No 2, 351-358.

Moleong, L. J. (1993). Metode Penelitian Kualitatif. Bandung: Remaja Rosdakarya

Muhadjir, N. (2000). Metode Penelitian Kualitatif. Yogyakarta: Rake Sarasin.

Mulyana, D. (2000). Ilmu Komunikasi Suatu Pengantar. Bandung: Remaja Rosdakarya.

Mulyana, D. (2001). Metode Penelitian Kualitatif. Bandung: Remaja Rosdakarya.

Peluso, N. L., \& Harwell, E. (2001). Territory, Custom, and Politics of Ethnic War in West Kalimantan, Indonesia. In N. L. Peluso, \& M. Watts, Violent Environment (p. 86). New York: Cornell University Press.

Smith, C. Q. (2012). The roots of violence and prospects for reconciliation : a case study of ethnic conflict in Central Kalimantan, Indonesia. Retrieved from www.agris.fao.org: http:// agris.fao.org/agris-search/search. do?recordID=US2012411029 